\title{
ASSESSMENT THE MORAL DON'TS IN THE NEWS SERVICES OF LOCAL TVS IN BAGHLAN
}

\author{
Ansarullah Omari
}

Article DOI: https://doi.org/10.36713/epra7287

DOI No: 10.36713/epra7287

\begin{abstract}
SUMMARY
Research subject (review of moral don'ts in the news service of Baghlan local TV). The question of the research is how local TV stations in Baghlan act in order to avoid moral don'ts in their news services? Moral don'ts, in fact, are the red lines in the field of individual and social ethics that obliges journalists to refrain from them in preparing news and reports. The aim of this study is to understand the commitment of journalists of Baghlan local TVs in refraining from ethical don'ts in producing news productions. The importance of the research is that the journalists and officials of the local TV stations in Baghlan, by studying it, should identify the moral don'ts in news service and make efforts to eliminate them, and this will lead to the advancement of ethical journalism.

Among the variables or moral don'ts (desecration, distortion of facts, promotion of slavery, and involvement in criminal and political issues, psychological warfare, sexual abuse, racial discrimination, ethnic discrimination and linguistic discrimination) have been studied in the Baghlan local TVs news services. The important findings of the study are that the relationship between four variables (desecration, distortion of facts, racial discrimination and ethnic discrimination) are meaningful in Baghlan local TVs news services; that its two variables (racial discrimination and ethnic discrimination) are common in all three TV stations (Baghlan National, Pasban and Tanwir) and the other two variables are only meaninful on Pasban TV.

The present article is based on the theory of social responsibility. In the theory of social responsibility, the media accept and implement certain obligations in society, including refraining from moral don'ts. The research method is a quantitative research method of survey or field type. The statistical population is Pul-e-Khumri city and the sample population were selected using non-random (targeted) sampling.
\end{abstract}

KEYWORDS: ethics, media ethics, television, news service, moral don'ts

\section{INTRODUCTION}

The social status of journalists in modern societies stems from their social duties and responsibilities. Telling the truth and defending the rights of citizens' freedoms is one of the most vital needs of the people in a democratic society, and these goals are taken care of and protected by journalists through professional activity and (considering moral values).

In order that citizens' rights not to be ignored by the media and discriminated against (racial, ethnic and linguistic), the functioning of the media must be subject to media laws and ethical principles; Because, by doing so, the media, on the one hand, can fully enjoy their rights and privileges, On the other hand, their journalists clearly cannot abuse their professional rights and privileges, and this helps to promote ethical (professional) journalism (1).

Violating and disregarding professional ethics (observing moral dos and avoiding moral don'ts) by the media has become a global concern today; because, the development of information technology on the one hand has become a social and cultural capital and on the other hand has circulated a large amount of this information among people in different societies. Recognizing the fact that in today's world, every citizen has access to information, information is one of their basic needs, and they use information to improve their quality of life. Therefore, it was concerned the world community about the accuracy, trusteeship (adherence to moral dos and avoidance of moral don'ts) in gathering news and preparing accurate reports. However, the important issue in the present study is that the news and reports of local TV stations in Baghlan are not provided correctly and with full trust and local TV reporters in Baghlan do not avoid from moral don'ts in producing their media products.

The aim of this study is to obtain the commitment of Baghlan local TV reporters to refrain from ethical requirements in producing news products. This research is also of particular importance in terms of application; 
it means, the journalists and officials of the local TV stations in Baghlan can identify the avoiding moral don'ts in news service and try to eliminate them.

\section{THE AIMS OF THE RESEARCH}

1. Receiving the commitment of local TV stations journalists in Baghlan for avoiding moral don'ts in producing news product.

\section{RESEARCH QUESTION}

1. How do the local media of Baghlan act in avoiding moral don'ts in their news service?

\section{THEORETICAL FOUNDATIONS}

This research has been done based on theoretical foundations of media; particularly, the theory of social responsibility. Setting up an article on this theory is effective and efficient for its scientific understanding. This theory is important because that the reporters must not only adhere to individual and social ethics in doing media work; rather, they are committed to the observance of moral dos and it refrains from committing moral don'ts. "Normative theories tell how ideological values and situations are formed and function in certain cases.' Normative theory is important; because, the formation of media institutions and how they are run by media owners have major effects" (2).

Normative theories explain the do's and don'ts of governing the media in different situations. These theories, which are binding and obligatory, have emerged from the condition of the media in different societies and times. These theories delineate the relationship between government, media, and society, and examine government expectations of the media, norms, conditions, and expectations regarding the social role of the media in different societies (3)

Social responsibility theory is a type of normative media theory that says; the media have fundamental duties in society and they must be committed to doing so, and finally the media must accept certain commitments about society and implement them (4). Therefore, in this study, we seek to find out how much local TV stations in Baghlan are committed to avoiding moral don'ts.

\section{RESEARCH METHOD}

Research Method of the present paper is the quantitative method research of survey type. Quantitative research is in fact the representation and manipulation of observations in order to describe and explain the phenomena that those observations reflect (5).

\section{6-1: Technique and Statistical Population of Research}

In the present study (Tanwir, Pasban and Baghlan national TV) are dependent variables, which are calculated and measured with independent variables (sacrilege, distortion of facts, entering racial, ethnic and linguistic, criminal discrimination, promoting Promiscuity, psychological warfare, misusing sexual crimes). The method of information collection is field or survey method. The information in this research have collected through questionnaires and the number of acceptable questionnaires are (133).

The statistical population of the study is Pul-e-Khumri city. The sample population have selected, using non-random (purposeful) sampling. In purposeful sampling, the units which are going to observe or study, selected based on the researcher's judgment about which units are more useful and reference. Information from the research was collected through questionnaires and was analyzed by SPSS program.

\section{RESEARCH BACKGROUND}

The title of the investigation (review of moral don'ts in the news service of Baghlan local TV stations) has not been determined yet; however, the authors, such as: Javideh Ahmadi wrote a book with entitled in 2011 (Principles of Media Ethics) which has eight chapters and its content is mostly devoted to general cases of ethics. Manijeh Bakhtari also wrote a book in 2007 with a entitled (Ethics and Law in Journalism) in seven chapters in which the author has studied the concept of ethics. Bakhtiari also has a proposal to prepare a moral charter for the country's media.

However, foreign writers have done a great deal of scientific work on media ethics, and the researcher points to several studies in this regard: Mohammad Haji Esmaili, Master of Hadith Sciences, majoring in Ethics, Quran and Hadith University, in 2014, has prepared an article entitled (Criteria of Islamic Ethics in Journalism), and in his/her research, he identifies seven ethical issues, which are: Not receiving bribes, fiduciary, honesty and avoiding lies, refraining from divulging secrets, refusing to enter people's privacy, social responsibility and correct worldview and job statu.

Mohammad Fouladi, another Iranian researcher, wrote an article in 2009 entitled (Journalistic Ethics; Injuries and Challenges). Fuladi, In his researches, states moral dos(Prominent virtues, telling the facts, 
trustworthiness and confidentiality, observance of intellectual property rights, observance of impartiality, being updated and correct analysis of issues, and contributing to the stability and mental peace of society) and considers (sacrilege, misusing Public confidence, distortion of facts and censorship, promoting corruption and Promiscuity, promoting rumors, psychological warfare and entering privacy) as moral don'ts. Fuladi, found cases Such as (dependence on sources of power and wealth, stealing scientific works, the role of organizational values and orientations in the selection of news, the role of power and wealth agent in news coverage, lack of employment of journalists in the media, publishing news with unknown sources, misusing criminal and sexual offenses and provoke ethnic and racial differences) as harms to journalism.

\section{RESEARCH LITERATURE 8-1 Ethics}

Amid dictionary has expressed the meaning of the collective morality of "creation" and its meaning as "good". The term "Akhlagh" is the English translation of "ethics" and refers to a rational process in which individuals apply a set of principles and criteria set by an external authority. In other words, ethics includes the do's and don'ts that, from a professional ethics perspective, oblige the journalist to observe.

Morality is also a set of principles and rules; Expresses the moral do's and don'ts in which there is a kind of independence from the person; such as: principles such as good and truthfulness and badness and lying that people learn from families or teachers and rely on society in some way and as a tool in the hands of society that is imposed on individuals, Morality in this sense is a social matter (6).

\section{8-2: Media Ethics}

Media ethics is a set of ethical principles, work and professional standards and individual commitments that form a structural and conceptual framework for the purpose of doing valuable professional work and guiding journalists and the activists of reporting arena to comply with ethical standards. Media ethics, in a real and practical way, does not only include the principles and criteria designed and presented by institutions and governments; Rather, media ethics involves knowing, understanding, and practicing ethical principles and concepts related to journalism and information work that help journalists and information activists in doing practical work so that they can do their work in a right and to agree with the principles of media ethics (7). Also, "media ethics" means introducing the theoretical framework that media owners are required to adhere to, so that adhering to its rules will eventually lead to practical ethics (8).

\section{8-3. Moral don'ts}

In addition to observing individual and collective ethics and respecting the moral values of society, journalists must also adhere to moral don'ts and refrain from committing them. Moral don'ts are the red line in the field of individual and social ethics that journalists are required to adhere to.

\section{8-3-1: Desecration}

Amid dictionary expresses the meaning of sanctity as follows: "What is not allowed to break or what is obligatory to maintain and protect and ". However, deception, harassment, invasion of privacy, misuse, abuse of subjects and people who have been oppressed, magnification of conflicts, suicide attacks, criminal incidents, Sexual assault and ... It all comes down to sacrilege. Therefore, the media should not desecrate their activities (9).

\section{8-3-2: Distortion of facts}

The media sometimes chooses news in order to achieve its internal goals; Pursue a policy of distorting the facts or selectivity of the news in various forms and abusing public trust; like the:

1. Zoom in on small facts to hide larger facts;

2. Denying or deleting a part of the truths of a subject, in order to distort the whole truth;

3. A fact with its specific analysis to distort the essence of the subject.

4. Expressing the truth and combining it with various lies to erase the effects and its result

5. Choosing words with a negative connotation to tell a valuable truth;

6. Inducing special political, economic, social, cultural, historical and scientific ideas in the form of (news and reports);

7. Destroying prominent, educated and influential personalities and promoting corruption

News and media reports are not only useful for all people due to their specific orientation; on the contrary, it has many effects, consequences and dangers. Although media messages are distorted; however, over time, the audience will believe their messages and follow their goals in the future, willingly or unwillingly (10). 


\section{8-3-3: Getting involved in criminal and political issues}

Analyzing political issues is a good thing; However, sometimes, instead of observing balance and neutrality in political issues and correct analysis of political and social realities due to belonging to a stream, the reporter propagates his/her policy and in practice Promotes, schism, divisions and destruction of individuals and streams, etc. in the society and this action is against the public Expediency of the society.

That criminal and political issue are always tense; the reporter must observe accuracy, fairness and impartiality (10). In this regard, Article 22 of the Afghan Public Media Law is subtitled (Balancing) Regarding political issues, he says: "Private radio and television departments should strike a balance between the factions and political figures taking a stand against each other and broadcast the views of the parties impartially"

\section{8-3-4: Promoting Promiscuity}

Afghanistan is an Islamic country and in an Islamic society, Adherence to values, norms, public decency, respect for individuals and respect for the privacy of individuals, the prohibition of divisions and differences between individuals, the avoidance of hypocrisy and hypocrisy is important and desirable; Therefore, the Promoting Promiscuity of red lines and moral musts in an Islamic society is considered and the media are required to observe them (9).

\section{8-3-5: Psychological warfare}

Psychological warfare is "to mass communication in modern political conflicts: the use of violence and more conventional methods of communication to achieve politico-military goals (11). Currently, the media is the most important weapon for creating and streamlining psychological warfare and is used for purposes (political, military, economic, cultural, etc.); If journalists and reporters of news media, publish news and reports (correct, true, neutral and with the aim of creating an atmosphere of social belonging), the society will be moved towards empathy and The more the publication of news and their reports is far from reality and the incorrect attribution of articles in order to create an artificial atmosphere, the more it inflames the public space of society (10).

\section{8-3-6: Abuse of Sexual Crimes}

Abuse of people in any situation; it is an immoral act. Journalists and the media should not misuse people with dossiers related to sexual offences; Even if this act is not illegal, publishing the names, pictures of people, especially injured women, etc. is against chastity, ethics and public interests in an Islamic society. This is not only moral; but, the media law prohibits such information in order to destroy the personality of individuals at the community level; Therefore, journalists and the media should not mention the names of Sexual assault victims or publish material that reveals their identities; Unless there is no legal prohibition in this area (9).

\section{8-3-7: Racial Discrimination}

The media and journalists publish articles, directly or indirectly, that incite or cause war, violence, hatred and racism. Divisive issues among different groups of people, under any title, are considered wrongdoing, crime and immorality. The Afghan Constitution has such a view in this regard: (Any kind of discrimination and privilege between Afghan citizens is prohibited) (12).

\section{8-3-8: Ethnic and Linguistic Discrimination}

Journalists Because of belonging to a particular ethnic group and language defend them and take a stand against other ethnicities and languages. The media must refrain from inciting prejudice among the ethnic groups and languages of the country (10).

\section{RESEARCH FINDINGS}

\section{9-1. Description of research findings}

In this study, the researcher used a questionnaire as a data collection tool. According to the questions raised in the questionnaire, the most important research findings in the frequency distribution tables are described in the following table:

\begin{tabular}{|c|c|c|c|c|c|}
\hline \multicolumn{6}{|c|}{ Table1, gender of respondents } \\
\hline \multirow{2}{*}{ Gender of respondents } & Frequency & Percent & $\begin{array}{c}\text { Valid } \\
\text { Percent }\end{array}$ & $\begin{array}{c}\text { Cumulative } \\
\text { Percent }\end{array}$ \\
\hline \multirow{2}{*}{$\begin{array}{c}\text { Gender of } \\
\text { respondents }\end{array}$} & Woman & 40 & 30.1 & 30.1 & 30.1 \\
\cline { 2 - 6 } & Man & 93 & 69.9 & 69.9 & 69.9 \\
\cline { 2 - 6 } & Total & 133 & 100.0 & 100.0 & \\
\hline
\end{tabular}


Table1: According to the frequency of number (1) out of (133) respondents, the highest number of respondents $(69.9 \%)$ percent or (93) men and the lowest number of respondents $(30.1 \%)$ percent or 40 female.

\section{Graph No (1):}
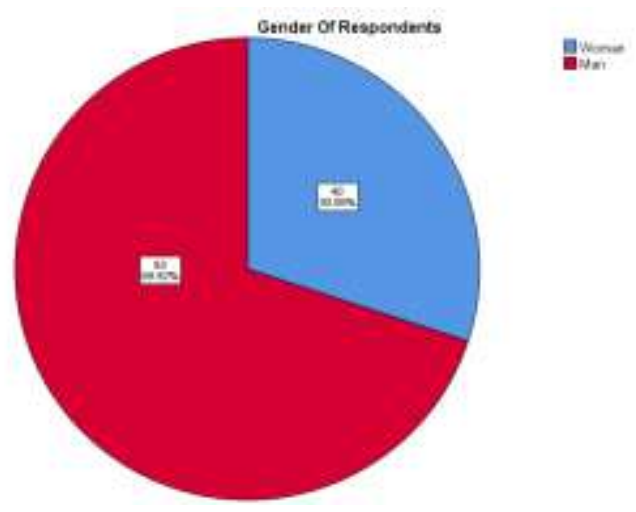

Table2, Civil condition of respondents

\begin{tabular}{|c|c|c|c|c|c|}
\hline \multicolumn{6}{|c|}{ Table2, Civil condition of respondents } \\
\hline \multicolumn{2}{|c|}{ Civil condition } & Frequency & Percent & Valid Percent & $\begin{array}{c}\text { Cumulative } \\
\text { Percent }\end{array}$ \\
\hline \multirow{3}{*}{$\begin{array}{c}\text { Civil } \\
\text { condition }\end{array}$} & Married & 28 & 21.1 & 21.1 & 21.1 \\
\hline & Single & 105 & 78.9 & 78.9 & 100.0 \\
\hline & Total & 133 & 100.0 & 100.0 & \\
\hline
\end{tabular}

Table2: According to the frequency table, number (2) of the total (133) respondents, the highest respondent $(78.9 \%)$ percent or (105) single and the lowest number of respondents $(21.1 \%)$ percent or (28) people are married.

\section{Graph No (2):}

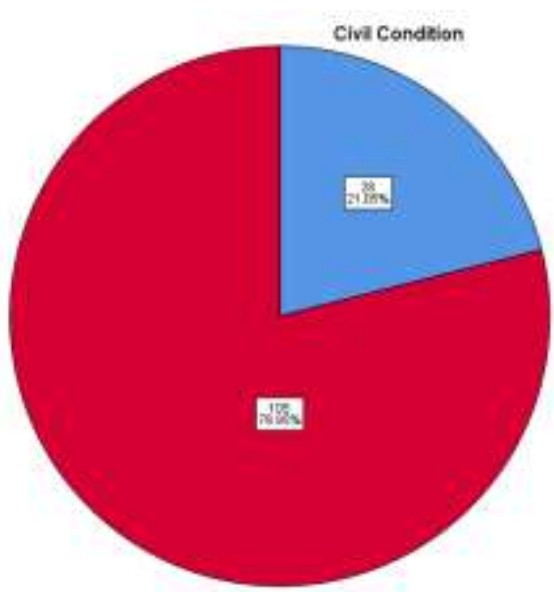

Table(3), Degrees of education of respondents

\begin{tabular}{|c|l|c|c|c|c|}
\hline \multicolumn{5}{|c|}{ Table(3), Degrees of education of respondents } \\
\hline \multicolumn{2}{|c|}{ Education degree } & Frequency & Percent & Valid Percent & $\begin{array}{c}\text { Cumulative } \\
\text { Percent }\end{array}$ \\
\hline \multirow{4}{*}{$\begin{array}{c}\text { Education } \\
\text { degree }\end{array}$} & Graduate12 & 10 & 7.5 & 7.5 & 7.5 \\
\cline { 2 - 6 } & Graduate14 & 20 & 15.0 & 15.0 & 22.6 \\
\cline { 2 - 6 } & Bachelor & 100 & 75.2 & 75.2 & 97.7 \\
\cline { 2 - 6 } & master & 1 & .8 & .8 & 98.5 \\
\cline { 2 - 6 } & P.H.D & 2 & 1.5 & 1.5 & 100.0 \\
\cline { 2 - 6 } & Total & 133 & 100.0 & 100.0 & \\
\hline
\end{tabular}


In table3: According to the frequency table number (3) from the total of (133) respondents, the most respondent (75.2\%) percent or (100) people with a bachelor's degree, $(7.5 \%)$ or (10) graduate $12,(1.5 \%)$ percent or (2) P. HDs and the lowest number of respondents, $(0.8 \%)$ percent or (1) have a master's degree.

\section{Graph No3:}
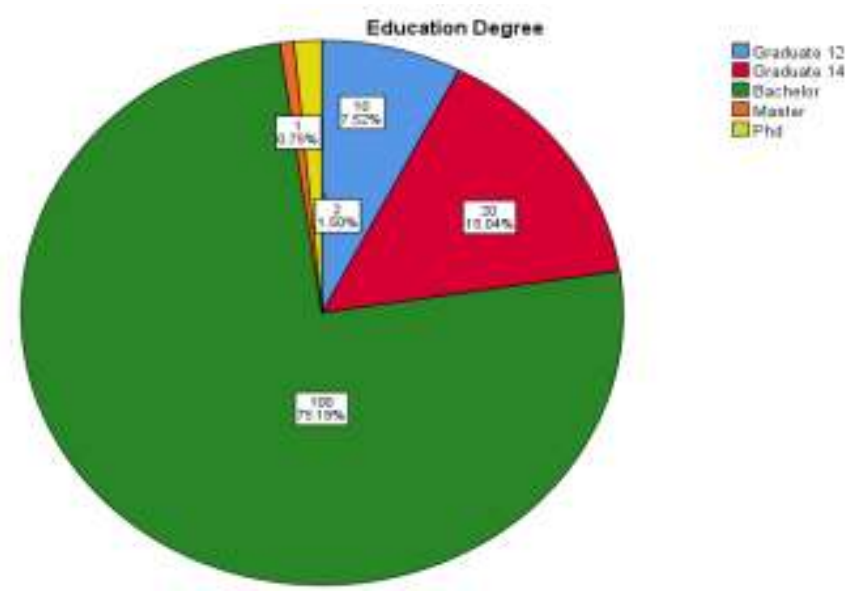

\begin{tabular}{|c|l|c|c|c|c|}
\hline \multicolumn{6}{|c|}{ Table (4), The duty of the respondents } \\
\hline \multirow{2}{*}{ The duty of the respondents } & Frequency & Percent & $\begin{array}{c}\text { Valid } \\
\text { Percent }\end{array}$ & $\begin{array}{c}\text { Cumulative } \\
\text { Percent }\end{array}$ \\
\hline \multirow{3}{*}{$\begin{array}{c}\text { The duty of the } \\
\text { respondents }\end{array}$} & employer & 2 & 1.5 & 1.5 & 1.5 \\
\cline { 2 - 6 } & annalist & 15 & 11.3 & 11.3 & 12.8 \\
\cline { 2 - 6 } & Journalism student & 19 & 14.3 & 14.3 & 27.1 \\
\cline { 2 - 6 } & Other & 97 & 72.9 & 72.9 & 100.0 \\
\cline { 2 - 6 } & Total & 133 & 100.0 & 100.0 & \\
\hline
\end{tabular}

Table NO4: according to the frequency table $\mathrm{NO}(4)$ out of (133) respondents, the highest number of respondents(72.9\%) percent or (97) people have various duties, (14.3\%) percent or (19) are journalism students, (11.3\%) percent or (15) were local media reporters, and (1.5\%) percent or (2) people are employers.

\section{Graph NO 4:}

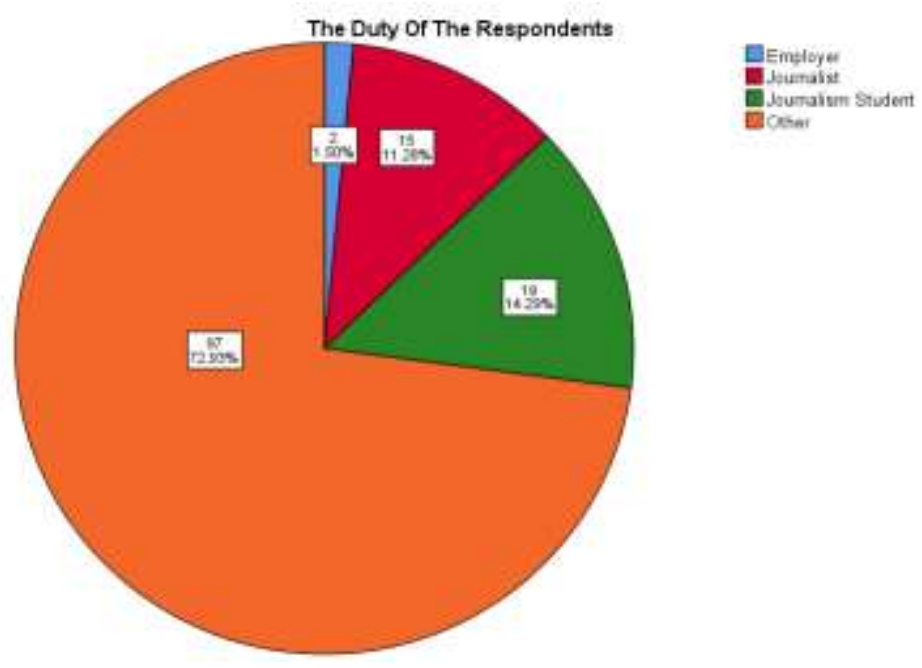




\begin{tabular}{|l|l|c|c|c|c|}
\hline \multicolumn{6}{|c|}{ Table(5), what is the level of sacrilege in Baghlan TV news services } \\
\hline \multicolumn{2}{|c|}{ Sacrilege } & Frequency & Percent & $\begin{array}{c}\text { Valid } \\
\text { Percent }\end{array}$ & $\begin{array}{c}\text { Cumulative } \\
\text { Percent }\end{array}$ \\
\hline \multirow{3}{*}{ Sacrilege } & Very little & 27 & 20.3 & 20.3 & 20.3 \\
\cline { 2 - 6 } & little & 31 & 23.3 & 23.3 & 43.6 \\
\cline { 2 - 6 } & average & 45 & 33.8 & 33.8 & 77.4 \\
\cline { 2 - 6 } & many & 18 & 13.5 & 13.5 & 91.0 \\
\cline { 2 - 6 } & perfectly & 12 & 9.0 & 9.0 & 100.0 \\
\cline { 2 - 6 } & Total & 133 & 100.0 & 100.0 & \\
\hline
\end{tabular}

Total5: According to table5, in terms of sacrilege in the news service of Baghlan TVs, out of a total of (133) respondents, the highest response rate $33.8 \%$ ) or the average response rate (45) is medium and the lowest response rate $(9.0 \%)$ percent or (12) people is a very high option.

\section{Graph (5):}

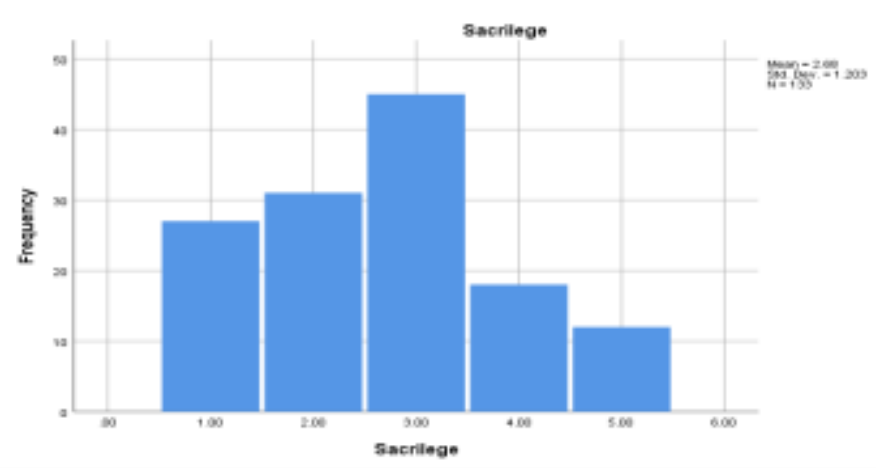

\begin{tabular}{|c|c|c|c|c|c|}
\hline \multicolumn{6}{|c|}{ Table(6) How Much is the Distortion of the Facts in the News Service Of Baghlan Local TV } \\
\hline \multicolumn{2}{|c|}{ Distortion of facts } & Frequency & Percent & $\begin{array}{l}\text { Valid } \\
\text { Percent }\end{array}$ & Cumulative \\
\hline \multirow{6}{*}{ Distortion of facts } & Very little & 18 & 13.5 & 13.5 & 13.5 \\
\hline & Little & 29 & 21.8 & 21.8 & 35.3 \\
\hline & Average & 39 & 29.3 & 29.3 & 64.7 \\
\hline & Many & 24 & 18.0 & 18.0 & 82.7 \\
\hline & Perfectly & 23 & 17.3 & 17.3 & 100.0 \\
\hline & Total & 133 & 100.0 & 100.0 & \\
\hline
\end{tabular}

Table 6: according table 6, in terms of fact-finding in the news service of Baghlan local TVs, out of a total of (133) respondents, the highest response rate is $(29.3 \%)$ or the average response rate is(39)and the lowest response rate $(13.50 \%)$ percent or (18) people is a very small option.

\section{Graph (6):}

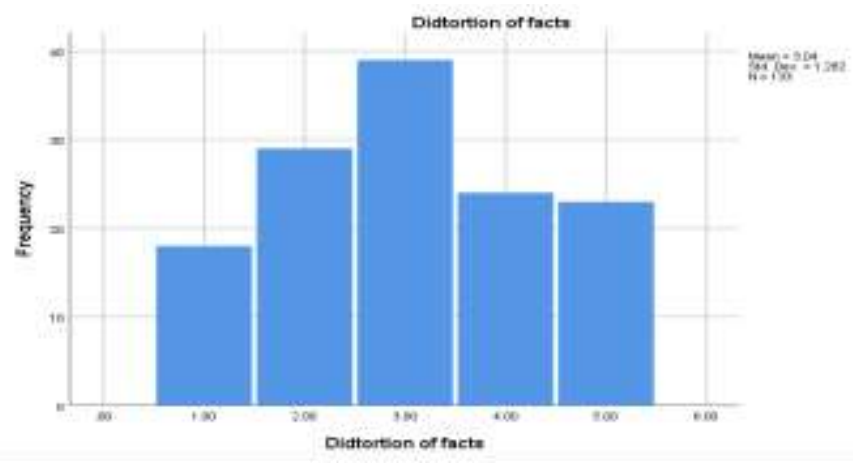




\begin{tabular}{|c|l|c|c|c|c|}
\hline \multicolumn{6}{|c|}{ table(7) How Much Is The Racial Discrimination In The News Service Of Baghlan Local TV } \\
\hline \multirow{2}{*}{ Racial discrimination } & Frequency & Percent & $\begin{array}{c}\text { Valid } \\
\text { Percent }\end{array}$ & $\begin{array}{c}\text { Cumulative } \\
\text { Percent }\end{array}$ \\
\hline \multirow{4}{*}{$\begin{array}{c}\text { Racial } \\
\text { discrimination }\end{array}$} & Very little & 28 & 21.1 & 21.1 & 21.1 \\
\cline { 2 - 6 } & Little & 24 & 18.0 & 18.0 & 39.1 \\
\cline { 2 - 6 } & Average & 33 & 24.8 & 24.8 & 63.9 \\
\cline { 2 - 6 } & Many & 17 & 12.8 & 12.8 & 76.7 \\
\cline { 2 - 6 } & Perfectly & 31 & 23.3 & 23.3 & 100.0 \\
\cline { 2 - 6 } & Total & 133 & 100.0 & 100.0 & \\
\hline
\end{tabular}

Table NO7: according to table $\mathrm{NO}(7)$, in terms of racial discrimination in the news service of local TVs in Baghlan, out of a Total of (133) respondents, The highest response(23.3\%) percent or (31) people is a very high choice and the lowest response (12.8\%) percent or (17) people is a high choice.

\section{Graph N07:}

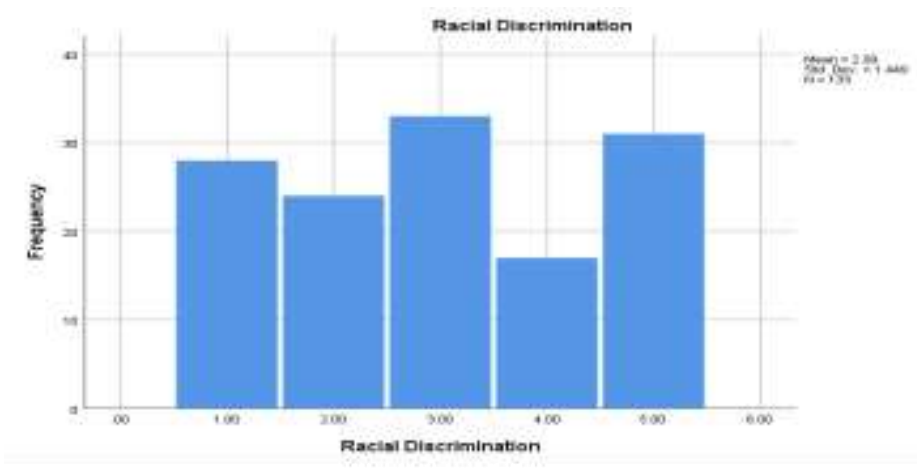

\begin{tabular}{|c|l|c|c|c|c|}
\hline \multicolumn{6}{|c|}{ Table(8) How Much is the Ethnic Discrimination in the News Service of Baghlan local TV } \\
\hline \multirow{2}{*}{ Ethnic Discrimination } & $\begin{array}{c}\text { Frequen } \\
\text { cy }\end{array}$ & $\begin{array}{c}\text { Percen } \\
\text { t }\end{array}$ & Valid Percent & $\begin{array}{c}\text { Cumulative } \\
\text { Percent }\end{array}$ \\
\hline \multirow{5}{*}{$\begin{array}{c}\text { ethnic } \\
\text { discrimination }\end{array}$} & Very little & 27 & 20.3 & 20.3 & 20.3 \\
\cline { 2 - 6 } & Little & 24 & 18.0 & 18.0 & 38.3 \\
\cline { 2 - 6 } & Average & 34 & 25.6 & 25.6 & 63.9 \\
\cline { 2 - 6 } & Many & 22 & 16.5 & 16.5 & 80.5 \\
\cline { 2 - 6 } & Perfectly & 26 & 19.5 & 19.5 & 100.0 \\
\cline { 2 - 6 } & Total & 133 & 100.0 & 100.0 & \\
\hline
\end{tabular}

Table NO8: according to table $\mathrm{NO}(8)$ in terms of ethnic discrimination in the news service of local TVs in Baghlan, out of total of (133) respondents, the highest response(25.3\%) percent or (34) people is the average option and the lowest response $(19.5 \%)$ or (26) people is the very high options.

Graph NO (8):

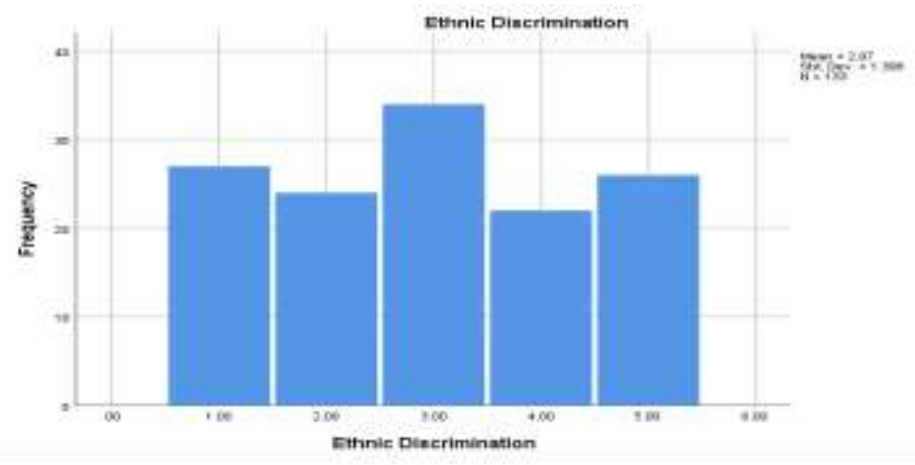




\section{9-2: Analysis of Research Findings}

In the present study (national television, Tanvir and Pasban) are dependent variables with independent variables (desecration, distortion of facts, involvement in criminal and political issues, Promoting Promiscuity, psychological warfare, sexual abuse, racial discrimination, Ethnic discrimination and linguistic discrimination) have been studied.

Hypothesis 1: There seems to be a relationship between Tanvir local television and the fact that there is racial discrimination in the Baghlan local television news service.

\begin{tabular}{|c|c|c|c|c|c|c|c|c|}
\hline \multirow{2}{*}{\multicolumn{3}{|c|}{$\begin{array}{l}\text { Table 1. The relationsh } \\
\text { discrimin } \\
\text { The relationship between Local } \\
\text { enlightenment TV and ethical } \\
\text { needs }\end{array}$}} & \multicolumn{5}{|c|}{ Racial discrimination on Tanvir local TV } & \multirow{3}{*}{$\begin{array}{c}\text { Total } \\
28 \\
\end{array}$} \\
\hline & & & \multirow{2}{*}{$\begin{array}{c}\text { Very little } \\
6 \\
\end{array}$} & \multirow{2}{*}{$\begin{array}{r}\text { Little } \\
1\end{array}$} & \multirow{2}{*}{$\begin{array}{c}\text { Average } \\
10 \\
\end{array}$} & \multirow{2}{*}{$\begin{array}{c}\text { Many } \\
7 \\
\end{array}$} & \multirow{2}{*}{$\begin{array}{c}\text { Perfectly } \\
4 \\
\end{array}$} & \\
\hline \multirow{20}{*}{ 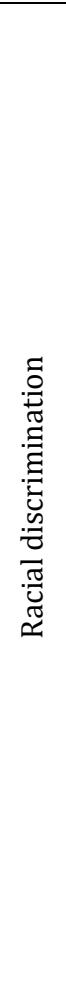 } & \multirow{4}{*}{$\begin{array}{l}\stackrel{0}{ \pm} \\
\stackrel{0}{0} \\
>0\end{array}$} & Count & & & & & & \\
\hline & & Line percent & $21.4 \%$ & $3.6 \%$ & $35.7 \%$ & $25.0 \%$ & $14.3 \%$ & $\begin{array}{c}100.0 \\
\%\end{array}$ \\
\hline & & Colum percent & $23.1 \%$ & $4.2 \%$ & $20.8 \%$ & $38.9 \%$ & $23.5 \%$ & $21.1 \%$ \\
\hline & & Total & $4.5 \%$ & $0.8 \%$ & $7.5 \%$ & $5.3 \%$ & $3.0 \%$ & $21.1 \%$ \\
\hline & \multirow{4}{*}{ 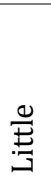 } & Count & 2 & 4 & 10 & 6 & 2 & 24 \\
\hline & & Line percent & $8.3 \%$ & $16.7 \%$ & $41.7 \%$ & $25.0 \%$ & $8.3 \%$ & $\begin{array}{c}100.0 \\
\%\end{array}$ \\
\hline & & Colum percent & $7.7 \%$ & $16.7 \%$ & $20.8 \%$ & $33.3 \%$ & $11.8 \%$ & $18.0 \%$ \\
\hline & & Total & $1.5 \%$ & $3.0 \%$ & $7.5 \%$ & $4.5 \%$ & $1.5 \%$ & $18.0 \%$ \\
\hline & \multirow{4}{*}{$\begin{array}{l}8 \\
\frac{\pi}{0} \\
\frac{\pi}{2} \\
2\end{array}$} & Count & 6 & 7 & 14 & 3 & 3 & 33 \\
\hline & & Line percent & $18.2 \%$ & $21.2 \%$ & $42.4 \%$ & $9.1 \%$ & $9.1 \%$ & $\begin{array}{c}100.0 \\
\%\end{array}$ \\
\hline & & Colum percent & $23.1 \%$ & $29.2 \%$ & $29.2 \%$ & $16.7 \%$ & $17.6 \%$ & $24.8 \%$ \\
\hline & & Total & $4.5 \%$ & $5.3 \%$ & $10.5 \%$ & $2.3 \%$ & $2.3 \%$ & $24.8 \%$ \\
\hline & \multirow{4}{*}{ 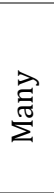 } & Count & 5 & 6 & 6 & 0 & 0 & 17 \\
\hline & & Line percent & $29.4 \%$ & $35.3 \%$ & $35.3 \%$ & $0.0 \%$ & $0.0 \%$ & $\begin{array}{c}100.0 \\
\%\end{array}$ \\
\hline & & Colum percent & $19.2 \%$ & $25.0 \%$ & $12.5 \%$ & $0.0 \%$ & $0.0 \%$ & $12.8 \%$ \\
\hline & & Total & $3.8 \%$ & $4.5 \%$ & $4.5 \%$ & $0.0 \%$ & $0.0 \%$ & $12.8 \%$ \\
\hline & \multirow{4}{*}{$\begin{array}{l}\overrightarrow{\vec{U}} \\
\stackrel{0}{0} \\
0 \\
0\end{array}$} & Count & 7 & 6 & 8 & 2 & 8 & 31 \\
\hline & & Line percent & $22.6 \%$ & $19.4 \%$ & $25.8 \%$ & $6.5 \%$ & $25.8 \%$ & $\begin{array}{c}100.0 \\
\%\end{array}$ \\
\hline & & Colum percent & $26.9 \%$ & $25.0 \%$ & $16.7 \%$ & $11.1 \%$ & $47.1 \%$ & $23.3 \%$ \\
\hline & & Total & $5.3 \%$ & $4.5 \%$ & $6.0 \%$ & $1.5 \%$ & $6.0 \%$ & $23.3 \%$ \\
\hline \multirow{4}{*}{\multicolumn{2}{|c|}{ Total }} & Count & 26 & 24 & 48 & 18 & 17 & 133 \\
\hline & & Line percent & $19.5 \%$ & $18.0 \%$ & $36.1 \%$ & $13.5 \%$ & $12.8 \%$ & $\begin{array}{c}100.0 \\
\%\end{array}$ \\
\hline & & Colum percent & $100.0 \%$ & $100.0 \%$ & $100.0 \%$ & $\begin{array}{c}100.0 \\
\%\end{array}$ & $100.0 \%$ & $\begin{array}{c}100.0 \\
\%\end{array}$ \\
\hline & & Total & $19.5 \%$ & $18.0 \%$ & $36.1 \%$ & $13.5 \%$ & $12.8 \%$ & $\begin{array}{c}100.0 \\
\%\end{array}$ \\
\hline
\end{tabular}

\begin{tabular}{|c|c|c|c|}
\hline \multicolumn{4}{|c|}{ Chi-Square Tests } \\
\hline & Value & Df & Asymptotic Significance (2-sided) \\
\hline Pearson Chi-Square & $26.438^{\mathrm{a}}$ & 16 & .048 \\
\hline Likelihood Ratio & 30.742 & 16 & .015 \\
\hline Linear-by-Linear Association & 1.558 & 1 & .212 \\
\hline N of Valid Cases & 133 & & \\
\hline
\end{tabular}

a. 14 cells $(56.0 \%)$ have expected count less than 5 . The minimum expected count is 2.17 .

Table (1): The findings of the study show that there is a relationship with five percent error and 95 percent confidence between Tanvir local TV and that there is racial discrimination in the news service of Baghlan local TV according to the Chi-square test (26.438) and the degree of freedom (16). There is a 
relationship with five percent error and 95 percent confidence; in other words, there is a connection between Tanvir local television and the fact that there is racial discrimination in the Baghlan local television news service. In describing this table, it should be said: in the variable of racial discrimination in the news service of local TV stations in Baghlan; In the very low option, the highest ratio is average and the lowest ratio is low. In the low option, the highest ratio is average and the lowest ratio is very high and very low. In the medium option, the highest ratio is average and the lowest ratio is very high. In the high option, the highest ratio is moderate and low and the lowest ratio is high and high. In the high value option, the highest ratio is very high and medium and the lowest ratio is high.

Hypothesis 2: There seems to be a significant relationship between Tanvir local television and ethnic discrimination in the Baghlan local television news service.

\begin{tabular}{|c|c|c|c|c|c|c|c|c|}
\hline \multicolumn{9}{|c|}{$\begin{array}{l}\text { Table 2, The relationship between Tanvir local television and ethnic discrimination in the } \\
\text { Baghlan local television news service. }\end{array}$} \\
\hline \multirow{2}{*}{\multicolumn{3}{|c|}{$\begin{array}{l}\text { The Relationship Between Tnvir } \\
\text { Local TV and Moral don'ts }\end{array}$}} & \multicolumn{5}{|c|}{ thnic Discrimination on Tanwir Local TV } & \multirow{3}{*}{$\begin{array}{c}\text { Total } \\
27\end{array}$} \\
\hline & & & Very little & Little & Average & Many & Perfectly & \\
\hline \multirow{20}{*}{ 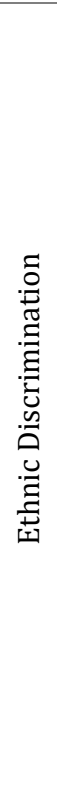 } & \multirow{4}{*}{ 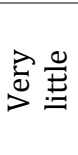 } & Count & 7 & 1 & 8 & 5 & 6 & \\
\hline & & Line percent & $25.9 \%$ & $3.7 \%$ & $29.6 \%$ & $18.5 \%$ & $22.2 \%$ & $100.0 \%$ \\
\hline & & Colum percent & $26.9 \%$ & $4.2 \%$ & $16.7 \%$ & $27.8 \%$ & $35.3 \%$ & $20.3 \%$ \\
\hline & & Total & $5.3 \%$ & $0.8 \%$ & $6.0 \%$ & $3.8 \%$ & $4.5 \%$ & $20.3 \%$ \\
\hline & \multirow{4}{*}{$\stackrel{\varrho}{\rightleftarrows}$} & Count & 1 & 4 & 12 & 6 & 1 & 24 \\
\hline & & Line percent & $4.2 \%$ & $16.7 \%$ & $50.0 \%$ & $25.0 \%$ & $4.2 \%$ & $100.0 \%$ \\
\hline & & Colum percent & $3.8 \%$ & $16.7 \%$ & $25.0 \%$ & $33.3 \%$ & $5.9 \%$ & $18.0 \%$ \\
\hline & & Total & $0.8 \%$ & $3.0 \%$ & $9.0 \%$ & $4.5 \%$ & $0.8 \%$ & $18.0 \%$ \\
\hline & \multirow{4}{*}{$\begin{array}{l}\mathbb{\infty} \\
\mathbb{\pi} \\
\stackrel{0}{0}\end{array}$} & Count & 5 & 10 & 13 & 4 & 2 & 34 \\
\hline & & Line percent & $14.7 \%$ & $29.4 \%$ & $38.2 \%$ & $11.8 \%$ & $5.9 \%$ & $100.0 \%$ \\
\hline & & Colum percent & $19.2 \%$ & $41.7 \%$ & $27.1 \%$ & $22.2 \%$ & $11.8 \%$ & $25.6 \%$ \\
\hline & & Total & $3.8 \%$ & $7.5 \%$ & $9.8 \%$ & $3.0 \%$ & $1.5 \%$ & $25.6 \%$ \\
\hline & \multirow{4}{*}{$\stackrel{\vec{\pi}}{\sum_{\Sigma}^{\pi}}$} & Count & 4 & 5 & 9 & 2 & 2 & 22 \\
\hline & & Line percent & $18.2 \%$ & $22.7 \%$ & $40.9 \%$ & $9.1 \%$ & $9.1 \%$ & $100.0 \%$ \\
\hline & & Colum percent & $15.4 \%$ & $20.8 \%$ & $18.8 \%$ & $11.1 \%$ & $11.8 \%$ & $16.5 \%$ \\
\hline & & Total & $3.0 \%$ & $3.8 \%$ & $6.8 \%$ & $1.5 \%$ & $1.5 \%$ & $16.5 \%$ \\
\hline & \multirow{4}{*}{ 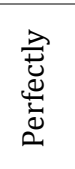 } & Count & 9 & 4 & 6 & 1 & 6 & 26 \\
\hline & & Line percent & $34.6 \%$ & $15.4 \%$ & $23.1 \%$ & $3.8 \%$ & $23.1 \%$ & $100.0 \%$ \\
\hline & & Colum percent & $34.6 \%$ & $16.7 \%$ & $12.5 \%$ & $5.6 \%$ & $35.3 \%$ & $19.5 \%$ \\
\hline & & Total & $6.8 \%$ & $3.0 \%$ & $4.5 \%$ & $0.8 \%$ & $4.5 \%$ & $19.5 \%$ \\
\hline \multirow{4}{*}{\multicolumn{2}{|c|}{ Total }} & Count & 26 & 24 & 48 & 18 & 17 & 133 \\
\hline & & Line percent & $19.5 \%$ & $18.0 \%$ & $36.1 \%$ & $13.5 \%$ & $12.8 \%$ & $100.0 \%$ \\
\hline & & Colum percent & $100.0 \%$ & $\begin{array}{c}100.0 \\
\%\end{array}$ & $\begin{array}{c}100.0 \\
\%\end{array}$ & $100.0 \%$ & $100.0 \%$ & $100.0 \%$ \\
\hline & & Total & $19.5 \%$ & $18.0 \%$ & $36.1 \%$ & $13.5 \%$ & $12.8 \%$ & $100.0 \%$ \\
\hline
\end{tabular}

\begin{tabular}{|c|c|c|c|}
\hline \multicolumn{4}{|c|}{ Chi-Square Tests } \\
\hline & Value & Df & Asymptotic Significance (2-sided) \\
\hline Pearson Chi-Square & $27.787^{\mathrm{a}}$ & 16 & .034 \\
\hline Likelihood Ratio & 30.065 & 16 & .018 \\
\hline Linear-by-Linear Association & 2.457 & 1 & .117 \\
\hline N of Valid Cases & 133 & & \\
\hline
\end{tabular}

a. 16 cells $(64.0 \%)$ have expected count less than 5 . The minimum expected count is 2.81 .

Table No. 2: The research findings show that there is ethnic discrimination between the Tanvir and the Baghlan local television news service; according to the Chi-square test (27.787) and the degree of freedom (16), there is a relationship with five percent error and 95 percent confidence, or in other words, between Tanvir local television, there is a significant relationship between Tanvir local television and the fact that there is ethnic discrimination in the news service of Baghlan local television. In describing this table, it should be said: In the variable of ethnic discrimination in the news service of local TV stations in Baghlan; in the very low option, the 
highest ratio is average and the lowest ratio is low. In the low option, the highest ratio is average and the lowest ratio is very high and very low. In the medium option, the highest ratio is moderate and the lowest ratio is very high. In the high option, the highest ratio is average and the lowest ratio is very high. In the high option, the highest ratio is very low and the lowest ratio is high.

Hypothesis 3: There seems to be a significant relationship between Pasban local TV and the fact that there is a sacrilege in the news service of Baghlan local TV.

\begin{tabular}{|c|c|c|c|c|c|c|c|c|}
\hline \multirow{3}{*}{\multicolumn{3}{|c|}{$\begin{array}{l}\text { Table 3. The relationship be } \\
\text { desecration in th } \\
\text { The relationship between the } \\
\text { Local TV of the Pasban and ethical } \\
\text { needs }\end{array}$}} & \multirow{4}{*}{\multicolumn{2}{|c|}{$\begin{array}{c}\text { cal TV of } \\
\text { e of the } \\
\text { sacrile } \\
\text { Little } \\
7\end{array}$}} & \multirow{2}{*}{\multicolumn{3}{|c|}{$\begin{array}{l}\text { he Pasban and the } \\
\text { cal TV stations in I } \\
\text { on Pasban local TV }\end{array}$}} & \multirow{4}{*}{\begin{tabular}{c|} 
Total \\
27 \\
\end{tabular}} \\
\hline & & & & & & & & \\
\hline & & & & & Average & Many & Perfectly & \\
\hline \multirow{20}{*}{ 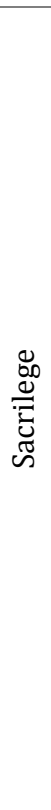 } & \multirow{4}{*}{ 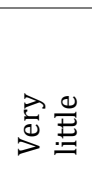 } & Count & & & 13 & 4 & 0 & \\
\hline & & Line percent & $11.1 \%$ & $25.9 \%$ & $48.1 \%$ & $14.8 \%$ & $0.0 \%$ & $100.0 \%$ \\
\hline & & Colum percent & $14.3 \%$ & $25.9 \%$ & $25.5 \%$ & $19.0 \%$ & $0.0 \%$ & $20.3 \%$ \\
\hline & & Total & $2.3 \%$ & $5.3 \%$ & $9.8 \%$ & $3.0 \%$ & $0.0 \%$ & $20.3 \%$ \\
\hline & \multirow{4}{*}{$\stackrel{\oplus}{:}$} & Count & 2 & 7 & 13 & 8 & 1 & 31 \\
\hline & & Line percent & $6.5 \%$ & $22.6 \%$ & $41.9 \%$ & $25.8 \%$ & $3.2 \%$ & $100.0 \%$ \\
\hline & & Colum percent & $9.5 \%$ & $25.9 \%$ & $25.5 \%$ & $38.1 \%$ & $7.7 \%$ & $23.3 \%$ \\
\hline & & Total & $1.5 \%$ & $5.3 \%$ & $9.8 \%$ & $6.0 \%$ & $0.8 \%$ & $23.3 \%$ \\
\hline & \multirow{4}{*}{ 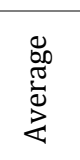 } & Count & 9 & 9 & 20 & 3 & 4 & 45 \\
\hline & & Line percent & $20.0 \%$ & $20.0 \%$ & $44.4 \%$ & $6.7 \%$ & $8.9 \%$ & $100.0 \%$ \\
\hline & & Colum percent & $42.9 \%$ & $33.3 \%$ & $39.2 \%$ & $14.3 \%$ & $30.8 \%$ & $33.8 \%$ \\
\hline & & Total & $6.8 \%$ & $6.8 \%$ & $15.0 \%$ & $2.3 \%$ & $3.0 \%$ & $33.8 \%$ \\
\hline & \multirow{4}{*}{ 己ે } & Count & 3 & 4 & 3 & 4 & 4 & 18 \\
\hline & & Line percent & $16.7 \%$ & $22.2 \%$ & $16.7 \%$ & $22.2 \%$ & $22.2 \%$ & $100.0 \%$ \\
\hline & & Colum percent & $14.3 \%$ & $14.8 \%$ & $5.9 \%$ & $19.0 \%$ & $30.8 \%$ & $13.5 \%$ \\
\hline & & Total & $2.3 \%$ & $3.0 \%$ & $2.3 \%$ & $3.0 \%$ & $3.0 \%$ & $13.5 \%$ \\
\hline & \multirow{4}{*}{ 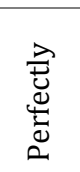 } & Count & 4 & 0 & 2 & 2 & 4 & 12 \\
\hline & & Line percent & $33.3 \%$ & $0.0 \%$ & $16.7 \%$ & $16.7 \%$ & $33.3 \%$ & $100.0 \%$ \\
\hline & & Colum percent & $19.0 \%$ & $0.0 \%$ & $3.9 \%$ & $9.5 \%$ & $30.8 \%$ & $9.0 \%$ \\
\hline & & Total & $3.0 \%$ & $0.0 \%$ & $1.5 \%$ & $1.5 \%$ & $3.0 \%$ & $9.0 \%$ \\
\hline \multirow{4}{*}{\multicolumn{2}{|c|}{ Total }} & Count & 21 & 27 & 51 & 21 & 13 & 133 \\
\hline & & Line percent & $15.8 \%$ & $20.3 \%$ & $38.3 \%$ & $15.8 \%$ & $9.8 \%$ & $100.0 \%$ \\
\hline & & Colum percent & $100.0 \%$ & $\begin{array}{c}100.0 \\
\%\end{array}$ & $100.0 \%$ & $\begin{array}{c}100.0 \\
\%\end{array}$ & $100.0 \%$ & $100.0 \%$ \\
\hline & & Total & $15.8 \%$ & $20.3 \%$ & $38.3 \%$ & $15.8 \%$ & $9.8 \%$ & $100.0 \%$ \\
\hline
\end{tabular}

\begin{tabular}{|c|c|c|c|}
\hline \multicolumn{4}{|c|}{ Chi-Square Tests } \\
\hline & Value & Df & Asymptotic Significance (2-sided) \\
\hline Pearson Chi-Square & $31.343^{\mathrm{a}}$ & 16 & .012 \\
\hline Likelihood Ratio & 34.590 & 16 & .005 \\
\hline Linear-by-Linear Association & 1.225 & 1 & .268 \\
\hline N of Valid Cases & 133 & & \\
\hline
\end{tabular}

a. 16 cells $(64.0 \%)$ have expected count less than 5 . The minimum expected count is 1.17 .

Table No. 3: The findings of the study show that there is a relationship with five percent error and 95 percent confidence between Tanvir local TV and that there is disecration in the news service of Baghlan local TV according to the Chi-square test (31.343) and the degree of freedom (16). In other words, there is a significant relationship between the Pasban local television and the disecration of facts in the Baghlan local television news service. In the desecration variable in Baghlan local TV news service; In the very low option, the highest ratio is moderate and the lowest ratio is very high. In the low option, the highest ratio is moderate and the lowest ratio is very high. In the medium option, the highest ratio is moderate and the lowest ratio is high. In the high option, the highest ratio is very high, high and low, and the lowest ratio is medium and very low. In the very high option, the highest ratio is very high and very low and the lowest ratio is low. 
Hypothesis 4: There seems to be a significant relationship between the local Pasban television and distortion of the facts in the news service of the Baghlan local television.

\begin{tabular}{|c|c|c|c|c|c|c|c|c|}
\hline \multicolumn{9}{|c|}{$\begin{array}{l}\text { Total 4. There is a connection between the Pasban and the distoration of the facts in the news } \\
\text { service of the local TV stations in Baghlan }\end{array}$} \\
\hline \multirow{2}{*}{\multicolumn{3}{|c|}{$\begin{array}{l}\text { The relationship between Pasban } \\
\text { TV and ethical needs }\end{array}$}} & \multicolumn{5}{|c|}{ Distortion of the facts on the local TV of the Pasban } & \multirow{3}{*}{$\begin{array}{c}\text { Total } \\
18\end{array}$} \\
\hline & & & \multirow{2}{*}{$\begin{array}{c}\text { Very little } \\
5\end{array}$} & \multirow{2}{*}{$\begin{array}{c}\text { Little } \\
3\end{array}$} & \multirow{2}{*}{$\begin{array}{c}\text { Average } \\
7\end{array}$} & \multirow{2}{*}{ Many } & \multirow{2}{*}{ Perfectly } & \\
\hline \multirow{20}{*}{ 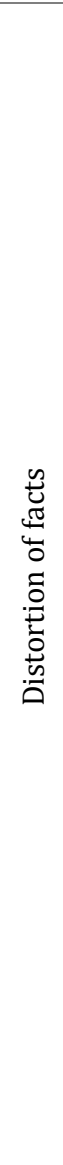 } & \multirow{4}{*}{ 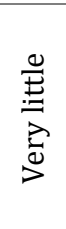 } & Count & & & & & & \\
\hline & & Line percent & $27.8 \%$ & $\begin{array}{c}16.7 \\
\%\end{array}$ & $38.9 \%$ & $\begin{array}{c}11.1 \\
\%\end{array}$ & $5.6 \%$ & $\begin{array}{c}100.0 \\
\%\end{array}$ \\
\hline & & Colum percent & $23.8 \%$ & $\begin{array}{c}11.1 \\
\%\end{array}$ & $13.7 \%$ & $9.5 \%$ & $7.7 \%$ & $13.5 \%$ \\
\hline & & Total & $3.8 \%$ & $2.3 \%$ & $5.3 \%$ & $1.5 \%$ & $0.8 \%$ & $13.5 \%$ \\
\hline & \multirow{4}{*}{$\stackrel{巳}{:}$} & Count & 5 & 5 & 13 & 5 & 1 & 29 \\
\hline & & Line percent & $17.2 \%$ & $\begin{array}{c}17.2 \\
\%\end{array}$ & $44.8 \%$ & $\begin{array}{c}17.2 \\
\%\end{array}$ & $3.4 \%$ & $\begin{array}{c}100.0 \\
\%\end{array}$ \\
\hline & & Colum percent & $23.8 \%$ & $\begin{array}{c}18.5 \\
\%\end{array}$ & $25.5 \%$ & $\begin{array}{c}23.8 \\
\%\end{array}$ & $7.7 \%$ & $21.8 \%$ \\
\hline & & Total & $3.8 \%$ & $3.8 \%$ & $9.8 \%$ & $3.8 \%$ & $0.8 \%$ & $21.8 \%$ \\
\hline & \multirow{4}{*}{ 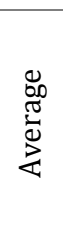 } & Count & 1 & 11 & 20 & 6 & 1 & 39 \\
\hline & & Line percent & $2.6 \%$ & $\begin{array}{c}28.2 \\
\%\end{array}$ & $51.3 \%$ & $\begin{array}{c}15.4 \\
\%\end{array}$ & $2.6 \%$ & $\begin{array}{c}100.0 \\
\%\end{array}$ \\
\hline & & Colum percent & $4.8 \%$ & $\begin{array}{c}40.7 \\
\% \\
\end{array}$ & $39.2 \%$ & $\begin{array}{c}28.6 \\
\%\end{array}$ & $7.7 \%$ & $29.3 \%$ \\
\hline & & Total & $0.8 \%$ & $8.3 \%$ & $15.0 \%$ & $4.5 \%$ & $0.8 \%$ & $29.3 \%$ \\
\hline & \multirow{4}{*}{ 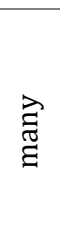 } & Count & 4 & 4 & 5 & 6 & 5 & 24 \\
\hline & & Line percent & $16.7 \%$ & $\begin{array}{c}16.7 \\
\%\end{array}$ & $20.8 \%$ & $\begin{array}{c}25.0 \\
\%\end{array}$ & $20.8 \%$ & $\begin{array}{c}100.0 \\
\%\end{array}$ \\
\hline & & Colum percent & $19.0 \%$ & $\begin{array}{c}14.8 \\
\%\end{array}$ & $9.8 \%$ & $\begin{array}{c}28.6 \\
\%\end{array}$ & $38.5 \%$ & $18.0 \%$ \\
\hline & & Total & $3.0 \%$ & $3.0 \%$ & $3.8 \%$ & $4.5 \%$ & $3.8 \%$ & $18.0 \%$ \\
\hline & \multirow{4}{*}{ 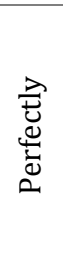 } & Count & 6 & 4 & 6 & 2 & 5 & 23 \\
\hline & & Line percent & $26.1 \%$ & $\begin{array}{c}17.4 \\
\%\end{array}$ & $26.1 \%$ & $8.7 \%$ & $21.7 \%$ & $\begin{array}{c}100.0 \\
\%\end{array}$ \\
\hline & & Colum percent & $28.6 \%$ & $\begin{array}{c}14.8 \\
\%\end{array}$ & $11.8 \%$ & $9.5 \%$ & $38.5 \%$ & $17.3 \%$ \\
\hline & & Total & $4.5 \%$ & $3.0 \%$ & $4.5 \%$ & $1.5 \%$ & $3.8 \%$ & $17.3 \%$ \\
\hline \multirow{4}{*}{\multicolumn{2}{|c|}{ Total }} & Count & 21 & 27 & 51 & 21 & 13 & 133 \\
\hline & & Line percent & $15.8 \%$ & $\begin{array}{c}20.3 \\
\%\end{array}$ & $38.3 \%$ & $\begin{array}{c}15.8 \\
\%\end{array}$ & $9.8 \%$ & $\begin{array}{c}100.0 \\
\%\end{array}$ \\
\hline & & Colum percent & $100.0 \%$ & $\begin{array}{c}100.0 \\
\%\end{array}$ & $100.0 \%$ & $\begin{array}{c}100 . \\
0 \%\end{array}$ & $100.0 \%$ & $\begin{array}{c}100.0 \\
\%\end{array}$ \\
\hline & & Total & $15.8 \%$ & $\begin{array}{c}20.3 \\
\%\end{array}$ & $38.3 \%$ & $\begin{array}{c}15.8 \\
\%\end{array}$ & $9.8 \%$ & $\begin{array}{c}100.0 \\
\%\end{array}$ \\
\hline
\end{tabular}

\begin{tabular}{|c|c|c|c|}
\hline \multicolumn{5}{|c|}{ Chi-Square Tests } \\
\hline & Value & Df & Asymptotic Significance (2-sided) \\
\hline Pearson Chi-Square & $26.375^{\text {a }}$ & 16 & .049 \\
\hline Likelihood Ratio & 28.077 & 16 & .031 \\
\hline Linear-by-Linear Association & 1.759 & 1 & .185 \\
\hline N of Valid Cases & 133 & & \\
\hline
\end{tabular}

a. 16 cells $(64.0 \%)$ have expected count less than 5 . The minimum expected count is 1.76 .

Table No. 4: The findings of the study show that there is a relationship with five percent error and 95 percent confidence between Tanvir local TV and that there is distortion of facts in the news service of Baghlan local TV according to the Chi-square test (26.375) and the degree of freedom (16). In other words, there is a significant relationship between the Pasban local television and the distortion of facts in the Baghlan local television news service. In the variable of distortion of facts in the news service of local TVs in Baghlan; in the very low option, the highest ratio is moderate and the lowest ratio is very high. In the low option, the highest ratio is moderate 
and the lowest ratio is very high. In the medium option, the highest ratio is moderate and the lowest ratio is very high and very low. In the high option, the highest ratio is the maximum and the lowest ratio is the low and very low. In the very high option, the highest ratio is moderate and very low and the lowest ratio is high.

Hypothesis 5: There seems to be a significant relationship between Pasban local television and racial discrimination in the Baghlan local television news service.

Total 5. The relationship between Pasban local TV and there is racial discrimination in the news service of Baghlan local TV

\begin{tabular}{|c|c|c|c|c|c|c|c|c|}
\hline \multirow{2}{*}{\multicolumn{3}{|c|}{$\begin{array}{l}\text { The relationship between Local TV } \\
\text { and ethical needs }\end{array}$}} & \multicolumn{5}{|c|}{ Racial discrimination on the Pasban local TV } & \multirow{2}{*}{ Total } \\
\hline & & & Very little & Little & Average & Many & Perfectly & \\
\hline \multirow{20}{*}{ 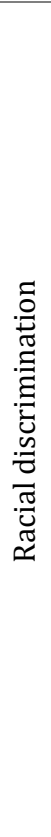 } & \multirow{4}{*}{ 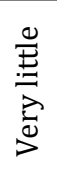 } & Count & 2 & 6 & 11 & 5 & 4 & 28 \\
\hline & & Line percent & $7.1 \%$ & $21.4 \%$ & $39.3 \%$ & $17.9 \%$ & $14.3 \%$ & $100.0 \%$ \\
\hline & & Colum percent & $9.5 \%$ & $22.2 \%$ & $21.6 \%$ & $23.8 \%$ & $30.8 \%$ & $21.1 \%$ \\
\hline & & Total & $1.5 \%$ & $4.5 \%$ & $8.3 \%$ & $3.8 \%$ & $3.0 \%$ & $21.1 \%$ \\
\hline & \multirow{4}{*}{$\stackrel{Ð}{\stackrel{\Xi}{\Xi}}$} & Count & 1 & 5 & 10 & 6 & 2 & 24 \\
\hline & & Line percent & $4.2 \%$ & $20.8 \%$ & $41.7 \%$ & $25.0 \%$ & $8.3 \%$ & $100.0 \%$ \\
\hline & & Colum percent & $4.8 \%$ & $18.5 \%$ & $19.6 \%$ & $28.6 \%$ & $15.4 \%$ & $18.0 \%$ \\
\hline & & Total & $0.8 \%$ & $3.8 \%$ & $7.5 \%$ & $4.5 \%$ & $1.5 \%$ & $18.0 \%$ \\
\hline & \multirow{4}{*}{ 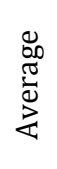 } & Count & 2 & 8 & 17 & 5 & 1 & 33 \\
\hline & & Line percent & $6.1 \%$ & $24.2 \%$ & $51.5 \%$ & $15.2 \%$ & $3.0 \%$ & $100.0 \%$ \\
\hline & & Colum percent & $9.5 \%$ & $29.6 \%$ & $33.3 \%$ & $23.8 \%$ & $7.7 \%$ & $24.8 \%$ \\
\hline & & Total & $1.5 \%$ & $6.0 \%$ & $12.8 \%$ & $3.8 \%$ & $0.8 \%$ & $24.8 \%$ \\
\hline & \multirow{4}{*}{$\begin{array}{l}\text { 己゙્ } \\
\text { ఏ }\end{array}$} & Count & 5 & 5 & 4 & 3 & 0 & 17 \\
\hline & & Line percent & $29.4 \%$ & $29.4 \%$ & $23.5 \%$ & $17.6 \%$ & $0.0 \%$ & $100.0 \%$ \\
\hline & & Colum percent & $23.8 \%$ & $18.5 \%$ & $7.8 \%$ & $14.3 \%$ & $0.0 \%$ & $12.8 \%$ \\
\hline & & Total & $3.8 \%$ & $3.8 \%$ & $3.0 \%$ & $2.3 \%$ & $0.0 \%$ & $12.8 \%$ \\
\hline & \multirow{4}{*}{ 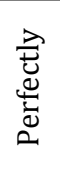 } & Count & 11 & 3 & 9 & 2 & 6 & 31 \\
\hline & & Line percent & $35.5 \%$ & $9.7 \%$ & $29.0 \%$ & $6.5 \%$ & $19.4 \%$ & $100.0 \%$ \\
\hline & & Colum percent & $52.4 \%$ & $11.1 \%$ & $17.6 \%$ & $9.5 \%$ & $46.2 \%$ & $23.3 \%$ \\
\hline & & Total & $8.3 \%$ & $2.3 \%$ & $6.8 \%$ & $1.5 \%$ & $4.5 \%$ & $23.3 \%$ \\
\hline \multirow{4}{*}{\multicolumn{2}{|c|}{ Total }} & Count & 21 & 27 & 51 & 21 & 13 & 133 \\
\hline & & Line percent & $15.8 \%$ & $20.3 \%$ & $38.3 \%$ & $15.8 \%$ & $9.8 \%$ & $100.0 \%$ \\
\hline & & Colum percent & $100.0 \%$ & $\begin{array}{c}100.0 \\
\%\end{array}$ & $100.0 \%$ & $\begin{array}{c}100.0 \\
\%\end{array}$ & $100.0 \%$ & $100.0 \%$ \\
\hline & & Total & $15.8 \%$ & $20.3 \%$ & $38.3 \%$ & $15.8 \%$ & $9.8 \%$ & $100.0 \%$ \\
\hline
\end{tabular}

\begin{tabular}{|c|c|c|c|}
\hline \multicolumn{4}{|c|}{ Chi-Square Tests } \\
\hline & Value & Df & Asymptotic Significance (2-sided) \\
\hline Pearson Chi-Square & $30.770^{\mathrm{a}}$ & 16 & .014 \\
\hline Likelihood Ratio & 32.366 & 16 & .009 \\
\hline Linear-by-Linear Association & 4.923 & 1 & .027 \\
\hline N of Valid Cases & 133 & & \\
\hline
\end{tabular}

a. 15 cells $(60.0 \%)$ have expected count less than 5 . The minimum expected count is 1.66 .

Table No. 5: The findings of the study show that there is a relationship with five percent error and 95 percent confidence between Tanvir local TV and that there is racial discrimination in the news service of Baghlan local TV according to the Chi-square test (30.770) and the degree of freedom (16). In other words, there is a connection between Pasban National Local Television and the fact that racial discrimination is present in the Baghlan Local Television news service. In the variable of racial discrimination in the news service of local TV stations in Baghlan; In the very low option, the highest ratio is the average limit and the lowest ratio is the very low limit. In the low option, the highest ratio is moderate and the lowest ratio is very low. In the medium option, the highest ratio is moderate and the lowest ratio is very high. In the high option, the highest ratio is the minimum and very low and the lowest ratio is the very high. In the highly priced option, the highest ratio is very low and the lowest ratio is high. 
Hypothesis 6: There seems to be a significant relationship between Pasban local television and ethnic discrimination in the Baghlan local television news service.

Table 6. The relationship between Pasban local TV and there is ethnic discrimination in the news service of Baghlan local TV.

\begin{tabular}{|c|c|c|c|c|c|c|c|c|}
\hline \multirow{2}{*}{\multicolumn{3}{|c|}{$\begin{array}{c}\text { The Relationship Between Local } \\
\text { enlightenment TV and ethical } \\
\text { needs }\end{array}$}} & \multicolumn{5}{|c|}{ Ethnic Discrimination On Pasban Local TV } & \multirow{3}{*}{$\begin{array}{c}\text { Total } \\
27 \\
\end{array}$} \\
\hline & & & \multirow{2}{*}{$\begin{array}{c}\text { Very little } \\
2\end{array}$} & \multirow{2}{*}{$\begin{array}{c}\text { Little } \\
5\end{array}$} & \multirow{2}{*}{$\begin{array}{c}\text { Average } \\
13\end{array}$} & \multirow{2}{*}{$\begin{array}{c}\text { Many } \\
4\end{array}$} & \multirow{2}{*}{$\begin{array}{c}\text { Perfectly } \\
3\end{array}$} & \\
\hline \multirow{20}{*}{ 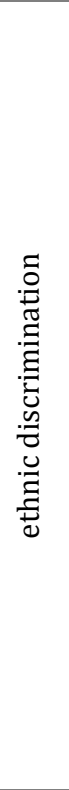 } & \multirow{4}{*}{$\begin{array}{l}\stackrel{0}{ \pm} \\
\stackrel{\Xi}{0} \\
\stackrel{0}{0} \\
>\end{array}$} & Count & & & & & & \\
\hline & & Line percent & $7.4 \%$ & $18.5 \%$ & $48.1 \%$ & $14.8 \%$ & $11.1 \%$ & $100.0 \%$ \\
\hline & & Colum percent & $9.5 \%$ & $18.5 \%$ & $25.5 \%$ & $19.0 \%$ & $23.1 \%$ & $20.3 \%$ \\
\hline & & Total & $1.5 \%$ & $3.8 \%$ & $9.8 \%$ & $3.0 \%$ & $2.3 \%$ & $20.3 \%$ \\
\hline & \multirow{4}{*}{$\stackrel{\oplus}{:}$} & Count & 1 & 6 & 10 & 6 & 1 & 24 \\
\hline & & Line percent & $4.2 \%$ & $25.0 \%$ & $41.7 \%$ & $25.0 \%$ & $4.2 \%$ & $100.0 \%$ \\
\hline & & Colum percent & $4.8 \%$ & $22.2 \%$ & $19.6 \%$ & $28.6 \%$ & $7.7 \%$ & $18.0 \%$ \\
\hline & & Total & $0.8 \%$ & $4.5 \%$ & $7.5 \%$ & $4.5 \%$ & $0.8 \%$ & $18.0 \%$ \\
\hline & \multirow{4}{*}{ 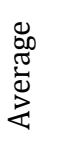 } & Count & 1 & 10 & 17 & 4 & 2 & 34 \\
\hline & & Line percent & $2.9 \%$ & $29.4 \%$ & $50.0 \%$ & $11.8 \%$ & $5.9 \%$ & $100.0 \%$ \\
\hline & & Colum percent & $4.8 \%$ & $37.0 \%$ & $33.3 \%$ & $19.0 \%$ & $15.4 \%$ & $25.6 \%$ \\
\hline & & Total & $0.8 \%$ & $7.5 \%$ & $12.8 \%$ & $3.0 \%$ & $1.5 \%$ & $25.6 \%$ \\
\hline & \multirow{4}{*}{ 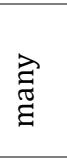 } & Count & 6 & 4 & 6 & 5 & 1 & 22 \\
\hline & & Line percent & $27.3 \%$ & $18.2 \%$ & $27.3 \%$ & $22.7 \%$ & $4.5 \%$ & $100.0 \%$ \\
\hline & & Colum percent & $28.6 \%$ & $14.8 \%$ & $11.8 \%$ & $23.8 \%$ & $7.7 \%$ & $16.5 \%$ \\
\hline & & Total & $4.5 \%$ & $3.0 \%$ & $4.5 \%$ & $3.8 \%$ & $0.8 \%$ & $16.5 \%$ \\
\hline & \multirow{4}{*}{ 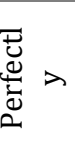 } & Count & 11 & 2 & 5 & 2 & 6 & 26 \\
\hline & & Line percent & $42.3 \%$ & $7.7 \%$ & $19.2 \%$ & $7.7 \%$ & $23.1 \%$ & $100.0 \%$ \\
\hline & & Colum percent & $52.4 \%$ & $7.4 \%$ & $9.8 \%$ & $9.5 \%$ & $46.2 \%$ & $19.5 \%$ \\
\hline & & Total & $8.3 \%$ & $1.5 \%$ & $3.8 \%$ & $1.5 \%$ & $4.5 \%$ & $19.5 \%$ \\
\hline \multirow{4}{*}{\multicolumn{2}{|c|}{ Total }} & Count & 21 & 27 & 51 & 21 & 13 & 133 \\
\hline & & Line percent & $15.8 \%$ & $20.3 \%$ & $38.3 \%$ & $15.8 \%$ & $9.8 \%$ & $100.0 \%$ \\
\hline & & Colum percent & $100.0 \%$ & $\begin{array}{c}100.0 \\
\%\end{array}$ & $100.0 \%$ & $\begin{array}{c}100.0 \\
\%\end{array}$ & $100.0 \%$ & $100.0 \%$ \\
\hline & & Total & $15.8 \%$ & $20.3 \%$ & $38.3 \%$ & $15.8 \%$ & $9.8 \%$ & $100.0 \%$ \\
\hline
\end{tabular}

\begin{tabular}{|c|c|c|c|}
\hline \multicolumn{4}{|c|}{ Chi-Square Tests } \\
\hline & Value & $\mathrm{df}$ & Asymptotic Significance (2-sided) \\
\hline Pearson Chi-Square & $39.211^{\mathrm{a}}$ & 16 & .001 \\
\hline Likelihood Ratio & 38.259 & 16 & .001 \\
\hline Linear-by-Linear Association & 2.845 & 1 & .092 \\
\hline N of Valid Cases & 133 & & \\
\hline
\end{tabular}

a. 15 cells $(60.0 \%)$ have expected count less than 5 . The minimum expected count is 2.15 .

Table No. 6: The findings of the study show that there is a relationship with five percent error and 95 percent confidence between Tanvir local TV and that there is Ethnic Discrimination in the news service of Baghlan local TV according to the Chi-square test (39.211) and the degree of freedom (16). In other words, there is a connection between Pasban National Local Television and the fact that Ethnic Discrimination is present in the Baghlan Local Television news service. In the variable of ethnic discrimination in the news service of local TV stations in Baghlan; in the very low option, the highest ratio is the average limit and the lowest ratio is the very low limit. In the low option, the highest ratio is average and the lowest ratio is very high and very low. In the medium option, the highest ratio is moderate and the lowest ratio is very low. In the high option, the highest ratio is moderate and very low and the lowest ratio is very high. In the highly priced option, the highest ratio is very low and the lowest ratio is high and low. 
Hypothesis 7: There seems to be a significant relationship between Baghlan local television and racial discrimination in the local television news service.

\begin{tabular}{|c|c|c|c|c|c|c|c|c|}
\hline \multicolumn{9}{|c|}{$\begin{array}{l}\text { Table 7. The relationship between Baghlan local TV and there is racial discrimination in the } \\
\text { news service of Baghlan local TV. }\end{array}$} \\
\hline \multirow{2}{*}{\multicolumn{3}{|c|}{$\begin{array}{l}\text { The Relationship Between Baghlan } \\
\text { national local TV and moral needs }\end{array}$}} & \multicolumn{5}{|c|}{ Racial Discrimination on Baghlan national local TV } & \multirow[b]{2}{*}{ Total } \\
\hline & & & Very little & Little & $\begin{array}{l}\text { Averag } \\
\text { e }\end{array}$ & Many & Perfectly & \\
\hline \multirow{20}{*}{ 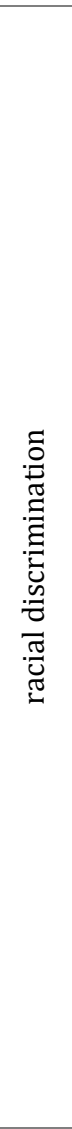 } & \multirow{4}{*}{ 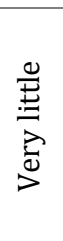 } & Count & 0 & 3 & 7 & 6 & 12 & 28 \\
\hline & & Line percent & $0.0 \%$ & $\begin{array}{c}10.7 \\
\%\end{array}$ & $25.0 \%$ & $21.4 \%$ & $42.9 \%$ & $100.0 \%$ \\
\hline & & Colum percent & $0.0 \%$ & $\begin{array}{c}18.8 \\
\%\end{array}$ & $25.0 \%$ & $17.6 \%$ & $26.7 \%$ & $21.1 \%$ \\
\hline & & Total & $0.0 \%$ & $2.3 \%$ & $5.3 \%$ & $4.5 \%$ & $9.0 \%$ & $21.1 \%$ \\
\hline & \multirow{4}{*}{$\stackrel{\oplus}{:}$} & Count & 0 & 2 & 8 & 9 & 5 & 24 \\
\hline & & Line percent & $0.0 \%$ & $8.3 \%$ & $33.3 \%$ & $37.5 \%$ & $20.8 \%$ & $100.0 \%$ \\
\hline & & Colum percent & $0.0 \%$ & $\begin{array}{c}12.5 \\
\%\end{array}$ & $28.6 \%$ & $26.5 \%$ & $11.1 \%$ & $18.0 \%$ \\
\hline & & Total & $0.0 \%$ & $1.5 \%$ & $6.0 \%$ & $6.8 \%$ & $3.8 \%$ & $18.0 \%$ \\
\hline & \multirow{4}{*}{ 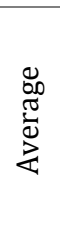 } & Count & 2 & 4 & 10 & 10 & 7 & 33 \\
\hline & & Line percent & $6.1 \%$ & $\begin{array}{c}12.1 \\
\%\end{array}$ & $30.3 \%$ & $30.3 \%$ & $21.2 \%$ & $100.0 \%$ \\
\hline & & Colum percent & $20.0 \%$ & $\begin{array}{c}25.0 \\
\%\end{array}$ & $35.7 \%$ & $29.4 \%$ & $15.6 \%$ & $24.8 \%$ \\
\hline & & Total & $1.5 \%$ & $3.0 \%$ & $7.5 \%$ & $7.5 \%$ & $5.3 \%$ & $24.8 \%$ \\
\hline & \multirow{4}{*}{$\underset{\Xi}{\overparen{\Xi}}$} & Count & 2 & 3 & 2 & 3 & 7 & 17 \\
\hline & & Line percent & $11.8 \%$ & $\begin{array}{c}17.6 \\
\%\end{array}$ & $11.8 \%$ & $17.6 \%$ & $41.2 \%$ & $100.0 \%$ \\
\hline & & Colum percent & $20.0 \%$ & $\begin{array}{l}18.8 \\
\%\end{array}$ & $7.1 \%$ & $8.8 \%$ & $15.6 \%$ & $12.8 \%$ \\
\hline & & Total & $1.5 \%$ & $2.3 \%$ & $1.5 \%$ & $2.3 \%$ & $5.3 \%$ & $12.8 \%$ \\
\hline & \multirow{4}{*}{ 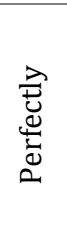 } & Count & 6 & 4 & 1 & 6 & 14 & 31 \\
\hline & & Line percent & $19.4 \%$ & $\begin{array}{c}12.9 \\
\%\end{array}$ & $3.2 \%$ & $19.4 \%$ & $45.2 \%$ & $100.0 \%$ \\
\hline & & Colum percent & $60.0 \%$ & $\begin{array}{c}25.0 \\
\%\end{array}$ & $3.6 \%$ & $17.6 \%$ & $31.1 \%$ & $23.3 \%$ \\
\hline & & Total & $4.5 \%$ & $3.0 \%$ & $0.8 \%$ & $4.5 \%$ & $10.5 \%$ & $23.3 \%$ \\
\hline \multirow{4}{*}{\multicolumn{2}{|c|}{ Total }} & Count & 10 & 16 & 28 & 34 & 45 & 133 \\
\hline & & Line percent & $7.5 \%$ & $\begin{array}{c}12.0 \\
\%\end{array}$ & $21.1 \%$ & $25.6 \%$ & $33.8 \%$ & $100.0 \%$ \\
\hline & & Colum percent & $100.0 \%$ & $\begin{array}{c}100.0 \\
\%\end{array}$ & $\begin{array}{c}100.0 \\
\%\end{array}$ & $\begin{array}{c}100.0 \\
\%\end{array}$ & $100.0 \%$ & $100.0 \%$ \\
\hline & & Total & $7.5 \%$ & $\begin{array}{c}12.0 \\
\%\end{array}$ & $21.1 \%$ & $25.6 \%$ & $33.8 \%$ & $100.0 \%$ \\
\hline
\end{tabular}

\begin{tabular}{|c|c|c|c|}
\hline & Chi-Square Tests \\
\hline & Value & Df & Asymptotic Significance (2-sided) \\
\hline Pearson Chi-Square & $27.181^{\mathrm{a}}$ & 16 & .040 \\
\hline Likelihood Ratio & 31.735 & 16 & .011 \\
\hline Linear-by-Linear Association & 1.333 & 1 & .248 \\
\hline N of Valid Cases & 133 & & \\
\hline
\end{tabular}

a. 12 cells $(48.0 \%)$ have expected count less than 5 . The minimum expected count is 1.28 .

Table 7. The findings of the study show that there is a relationship with five percent error and 95 percent confidence between Baghlan local TV and that there is racism in the news service of Baghlan local TV according to the Chi-square test (27.181) and the degree of freedom (16). In other words, there is a connection between Baghlan National Local Television and the fact that racism is present in the Baghlan Local Television news service. In the variable of racial discrimination in the news service of local TV stations in Baghlan; in the very low option, the highest ratio is very high and the lowest ratio is very low. In the low option, the highest 
ratio is high and the lowest ratio is very low. In the medium option, the highest ratio is high and medium and the lowest ratio is very low. In the large option, the highest ratio is very high and the lowest ratio is medium and very low. In the high value option, the highest (average) ratio is very high and the lowest ratio is medium.

Hypothesis 8: There seems to be a significant relationship between Baghlan local television and ethnic discrimination in the Baghlan local television news service.

\begin{tabular}{|c|c|c|c|c|c|c|c|c|}
\hline \multicolumn{9}{|c|}{$\begin{array}{l}\text { Total 8. The relationship between Baghlan national local TV and the fact there is ethnic } \\
\text { discrimination in the Baghlan local TV news service. }\end{array}$} \\
\hline \multirow{2}{*}{\multicolumn{3}{|c|}{$\begin{array}{c}\text { The relationship between } \\
\text { Baghlan national local TV and } \\
\text { moral needs }\end{array}$}} & \multicolumn{5}{|c|}{ ethnic discrimination on Baghlan local TV } & \multirow{3}{*}{$\begin{array}{c}\text { Total } \\
27\end{array}$} \\
\hline & & & \multirow{2}{*}{$\begin{array}{c}\text { Very little } \\
0\end{array}$} & \multirow{2}{*}{$\begin{array}{c}\text { Little } \\
2\end{array}$} & \multirow{2}{*}{$\begin{array}{c}\text { Average } \\
8\end{array}$} & \multirow{2}{*}{$\begin{array}{c}\text { Many } \\
6\end{array}$} & \multirow{2}{*}{$\begin{array}{c}\text { Perfectly } \\
11\end{array}$} & \\
\hline \multirow{20}{*}{ 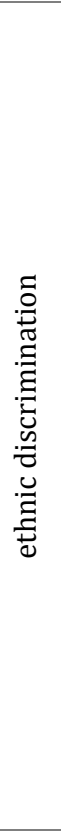 } & \multirow{4}{*}{ 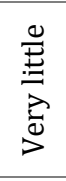 } & Count & & & & & & \\
\hline & & Line percent & $0.0 \%$ & $7.4 \%$ & $29.6 \%$ & $22.2 \%$ & $40.7 \%$ & $100.0 \%$ \\
\hline & & Colum percent & $0.0 \%$ & $12.5 \%$ & $28.6 \%$ & $17.6 \%$ & $24.4 \%$ & $20.3 \%$ \\
\hline & & Total & $0.0 \%$ & $1.5 \%$ & $6.0 \%$ & $4.5 \%$ & $8.3 \%$ & $20.3 \%$ \\
\hline & \multirow{4}{*}{$\stackrel{\oplus}{:}$} & Count & 1 & 0 & 7 & 10 & 6 & 24 \\
\hline & & Line percent & $4.2 \%$ & $0.0 \%$ & $29.2 \%$ & $41.7 \%$ & $25.0 \%$ & $100.0 \%$ \\
\hline & & Colum percent & $10.0 \%$ & $0.0 \%$ & $25.0 \%$ & $29.4 \%$ & $13.3 \%$ & $18.0 \%$ \\
\hline & & Total & $0.8 \%$ & $0.0 \%$ & $5.3 \%$ & $7.5 \%$ & $4.5 \%$ & $18.0 \%$ \\
\hline & \multirow{4}{*}{ 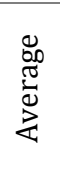 } & Count & 2 & 6 & 10 & 9 & 7 & 34 \\
\hline & & Line percent & $5.9 \%$ & $17.6 \%$ & $29.4 \%$ & $26.5 \%$ & $20.6 \%$ & $100.0 \%$ \\
\hline & & Colum percent & $20.0 \%$ & $37.5 \%$ & $35.7 \%$ & $26.5 \%$ & $15.6 \%$ & $25.6 \%$ \\
\hline & & Total & $1.5 \%$ & $4.5 \%$ & $7.5 \%$ & $6.8 \%$ & $5.3 \%$ & $25.6 \%$ \\
\hline & \multirow{4}{*}{ 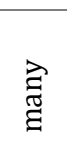 } & Count & 2 & 4 & 2 & 6 & 8 & 22 \\
\hline & & Line percent & $9.1 \%$ & $18.2 \%$ & $9.1 \%$ & $27.3 \%$ & $36.4 \%$ & $100.0 \%$ \\
\hline & & Colum percent & $20.0 \%$ & $25.0 \%$ & $7.1 \%$ & $17.6 \%$ & $17.8 \%$ & $16.5 \%$ \\
\hline & & Total & $1.5 \%$ & $3.0 \%$ & $1.5 \%$ & $4.5 \%$ & $6.0 \%$ & $16.5 \%$ \\
\hline & \multirow{4}{*}{ 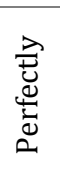 } & Count & 5 & 4 & 1 & 3 & 13 & 26 \\
\hline & & Line percent & $19.2 \%$ & $15.4 \%$ & $3.8 \%$ & $11.5 \%$ & $50.0 \%$ & $100.0 \%$ \\
\hline & & Colum percent & $50.0 \%$ & $25.0 \%$ & $3.6 \%$ & $8.8 \%$ & $28.9 \%$ & $19.5 \%$ \\
\hline & & Total & $3.8 \%$ & $3.0 \%$ & $0.8 \%$ & $2.3 \%$ & $9.8 \%$ & $19.5 \%$ \\
\hline \multirow{4}{*}{\multicolumn{2}{|c|}{ Total }} & Count & 10 & 16 & 28 & 34 & 45 & 133 \\
\hline & & Line percent & $7.5 \%$ & $12.0 \%$ & $21.1 \%$ & $25.6 \%$ & $33.8 \%$ & $100.0 \%$ \\
\hline & & Colum percent & $100.0 \%$ & $\begin{array}{c}100.0 \\
\%\end{array}$ & $100.0 \%$ & $\begin{array}{c}100.0 \\
\%\end{array}$ & $100.0 \%$ & $100.0 \%$ \\
\hline & & Total & $7.5 \%$ & $12.0 \%$ & $21.1 \%$ & $25.6 \%$ & $33.8 \%$ & $100.0 \%$ \\
\hline
\end{tabular}

\begin{tabular}{|c|c|c|c|}
\hline \multicolumn{4}{|c|}{ Chi-Square Tests } \\
\hline & Value & Df & Asymptotic Significance (2-sided) \\
\hline Pearson Chi-Square & $29.830^{\mathrm{a}}$ & 16 & .019 \\
\hline Likelihood Ratio & 35.407 & 16 & .003 \\
\hline Linear-by-Linear Association & 1.554 & 1 & .213 \\
\hline N of Valid Cases & 133 & & \\
\hline
\end{tabular}

a. 11 cells $(44.0 \%)$ have expected count less than 5 . The minimum expected count is 1.65 .

Table (8): The findings of the study show that there is a relationship with five percent error and 95 percent confidence between Baghlan local TV and that there is Ethnic discrimination in the news service of Baghlan local TV according to the Chi-square test (29.830) and the degree of freedom (16). In other words, there is a connection between Baghlan National Local Television and the fact that ethnic discrimination is present in the Baghlan Local Television news service. In the variable of ethnic discrimination in the news service of local TV stations in Baghlan; in the very low option, the highest ratio is very high and the lowest ratio is very low. 


\section{DISCUSSION AND CONCLUSION}

"Media ethics refers to the set of rules that media practitioners are required to follow voluntarily in the field of employment of their organizational professions" (13). Ethics is the broadest normative system that encompasses all levels of communication and no individual or social action is outside its scope. This research is based on normative theories of media; In particular, the theory of social responsibility has been done, which has important and useful results.

The most important result of this research are four cases of immorality, including (desecration, distortion of facts, racial discrimination and ethnic discrimination) in the news service of local TV stations in Baghlan. Racial discrimination and ethnic discrimination are common to all three local televisions (national, Pasbam, and Tanvir). The research findings show that these two variables are in the first row in Baghlan National TV, in the second row in Pasban TV and in the third place in Tanvir TV. In addition, Pasban TV also has a constable (desecration and distortion of facts). In addition, Pasban Tv has included the constable (desecration and distortion of facts). As saw in the description and analysis of the findings, local TV stations in Baghlan face media ethics challenges. This article is aimed at getting the commitment of Baghlan local TV reporters to refrain from moral don'ts; it can pave the way for further research.

\section{1: RECOURSES}

1. Forghani, Mohammad Mehdi (1393). Journal of Communication and Community Journalism. Tehran: Ettelaat Publications.

2. Amirpour, Mahnaz and Shafi' Bahramian. (1392.) General principles of mass communication theories. Tehran: Sociologists.

3. Babran, Siddiqeh and others. (1394). Charter of Professional Ethics in the Media. Quarterly Journal of Ethics in Science and Technology. Tenth year. Fourth Issue.

4. McQuail, Dennis. (1385). an Introduction to Mass Communication Theory. Translation: Parviz Ejlali. Tehran: Ministry of Culture and Islamic Guidance.

5. Baaby, Earl. (1390.) Research methods in social sciences. Translation: Reza Fazel. Volume II. Seventh edition. Tehran: Organization for the Study and Compilation of University Humanities Books.

6. Bashir, Hasan. (1392). Tehran: Imam Sadegh University publications.

7. Sarwari, Abdul Qahar (1396). Freedom of expression and journalistic ethics. Kabul: Hamed Resalat Publications.

8. Bashir, Hasan and Samaneh Azarpoor. (1390). "Ethics of blogging". Two Quarterly Journal of Interdisciplinary Studies in Media and Culture. First year. Second Issue.

9. Fouladi, Mohammad (1388). Journalistic ethics, injuries and challenges. Research Quarterly of bulletin of ethics. First year. Number four.

10. Ahmadi, Javideh. (1390.) Principles of media ethics. Kabul: Azem Publications.

11. Simpson, Christopher. (1396). Knowledge of communication and psychological warfare from 1945 to 1960. Translation: Mohammad Memarian. Tehran: Scientific and Cultural Publications.

12. Bakhtari, Manijeh. (1389.) Ethics and law in journalism. Second edition. Kabul: Saeed Publications

13. Sharafuddin, Seyed Hussein (1392). A religious approach to media ethics. With the focus on national media. Two specialized quarterly journals of Maarej Revelation Science Research Institute. Second year. Fifth issue. 